DOI: 10.20472/IAC.2019.050.024

\author{
ISMATILLA MARDANOV \\ Southeast Missouri State University, United States
}

\title{
THE DETERMINANTS OF ECONOMIC DEVELOPMENT OF GREECE
}

\begin{abstract}
:
Greece's specialization on tourism and service within the European Union (EU), the lack of its currency, monetary and financial dependence on the EU, and the weak voice in foreign trade decisions put Greece in economic turmoil and made the EU less effective in solving crucial problems in member countries. Using extended data, I have analyzed Greece's economic growth patterns for 46 years. The results indicate that protection of property rights, government consumption, and service industry had a significant and positive impact on economic growth while tax rates had a significant negative effect on GDP growth rates.
\end{abstract}

\section{Keywords:}

Greece, EU, Eurozone, economic growth, political and economic freedom, national debt, global financial crisis

JEL Classification: 010 


\section{Introduction}

The concept of the United States of Europe is not new. Napoleon Bonaparte, Victor Hugo, Giuseppe Garibaldi, John Stewart Mill, and others mentioned the idea of a single country similar to the United States of America. Germany was active in adopting an only constitution for the European Union. However, The French and Dutch blocked the idea in referenda. Treaties regulate relationships among EU nations.

The dependent variable is economic growth in various periods of Greece's history, independent variables are economic freedom indices, and the control variables are Greece's membership in the EU and Eurozone. Using extended data, I have analyzed Greece's economic growth patterns before and after Greece's political and economic integration into the EU and the entrance into the Eurozone. The results indicate that protection of property rights, government consumption, and service industry had a significant and positive impact on economic growth while tax rates had a significant negative effect on GDP growth rates. Manufacturing did not have a significant impact on Greece's economic growth. Economic growth rates would have been much higher if Greece was politically and economically independent, and the country had its own currency.

\section{Theoretical framework}

The literature questions the EU's institutional setup and legitimacy among its citizens (Dimitrova, 2010). Others see national polities (Schmidt, 2006) as the reasons for the problems. I understand that both are the reasons for low economic growth rates of the EU over so many years. Also, the China-factor played a significant role in the capital spillovers. In the second decade of the Eurozone, many countries encountered a real financial mess (Kuforiji, 2016). Also, the structural setup of economies of some peripheral countries under the division of labor in the EU might be a serious reason for the deep economic crisis in those countries. When a world economic crisis erupts, people stop spending on travel and tourism in the first place, which is the core of Greece's economy. The EU nations specialized in tourism were hit the most: Italy, Greece, Spain, and even Frances. These nations have been gradually losing their real economies, specifically manufacturing and construction.

\section{Hypotheses}

The limited political power of national governments in the EU hurts peripheral countries. Countries cannot make independent economic decisions. These countries had higher economic growth rates before becoming members of the EU. Comparisons of GDP growth rates before joining the EU and Eurozone and after indicates that, in 1970-1979, Greece achieved annual GDP growth rates of $5.0 \%{ }^{*}$ while after joining the EU, in 19812016, the annual growth rates were $0.8 \%$. After entering the Eurozone in 2001, the yearly economic growth rate was $-0.072 \%$. 
The Greek economic miracle created by an independent nation was destroyed (Rinegar, 2012) by its adventure to be a member of a union. Non-member European countries achieved higher GDP growth rates in the period when Greece was a member of the EU. Switzerland had average annual growth rates of $1.7 \%$, Norway $2.44 \%$, Iceland $3.48 \%$, and Greenland $3.76 \%$. During the post-crisis period 2010-2016, the average annual economic growth rates were $-3.245 \%$ in Greece, $1.8 \%$ in Switzerland, $1.5 \%$ in Norway, $2.03 \%$ in Greenland, and 2.57 in Iceland.

Hypothesis 1. Economic growth rates will be much higher if a country is politically and economically independent.

The most influential European countries preserved their real economies. They do not narrowly specialize in one or two key industries. They have enough money reserves and higher economic growth rates. The weaker countries experience an economic decline or stagnation and the deficit of budgets because of the narrowly specialized economies. Several such nations were bailed out by the EU. The primary lender of the bail-out funds was Germany. When economic problems occur, independent national currency can be depreciated to improve the national trade balance (Dudin, Gayduk, Sekeringm Bank, Gorobova, 2016). It is imperative that a country without own currency cannot make independent decisions in times of crisis or prosperity. The absence of own currency mainly caused Greece's decline. Greece can borrow only instead of doing cash emission.

Hypothesis 2: Economic growth rates will be much higher if a country has its own currency and economic sovereignty.

As soon as Greece had become a member of the EU, the share of government consumption and transfers and subsidies increased substantially (Pegkas, 2018). My calculations indicate that in 1985, by the end of the first five years of the EU membership, the government transfers and subsidies increased by $310 \%$.

\section{Method}

The sources of the publicly available data are the Frazer Institute and the World Bank. The data are for 1970-2016. I run economic freedom, government spending, employment rates, protection of property rates, the structure of the economy, and some other indicators against economic growth rates. I analyzed Greece's economic growth before joining the EU, while being a member of the $\mathrm{EU}$, and since joining the Eurozone in multiple regression. The dependent variable is economic growth in various periods of Greece's history, independent variables are economic freedom indices, and the control variables are Greece's membership in the EU and Eurozone. 


\section{Analyses and results}

Comparisons of GDP growth rates before joining the EU and Eurozone and after indicates that, in 1970-1979, Greece achieved annual GDP growth rates of 5.0\%* while after joining the EU, in 1981-2016, the annual growth rates were $0.8 \%$. After entering the Eurozone in 2001, the yearly economic growth rate was $-0.072 \%$. Non-member European countries achieved higher GDP growth rates in the period when Greece was a member of the EU. Switzerland had average annual growth rates of $1.7 \%$, Norway $2.44 \%$, Iceland $3.48 \%$, and Greenland 3.76\%. During the post-financial-crisis period 2010-2016, the average annual economic growth rates were $-3.245 \%$ in Greece, $1.8 \%$ in Switzerland, $1.5 \%$ in Norway, $2.03 \%$ in Greenland, and 2.57 in Iceland.

The results of analyses of the GDP growth rates (independent variable) influenced by a variety of factors indicate that the large size of government has a significant positive correlation (Table 1) with the low economic growth rates. Also, government consumption and government transfers and subsidies have a similar correlation with the low economic growth rates. Unemployment and diminishing manufacturing had a significant positive correlation with the low GDP growth rates.

Table1: Correlations among key economic indicators and GDP growth rates in Greece (N = 46 years)

\begin{tabular}{|c|c|c|c|c|c|c|c|c|c|c|}
\hline & gdpgr & ef & sog & ppr & gcon & ts & $\operatorname{tax}$ & ind & ser & emp \\
\hline GDP growth rates (\%) (gdpgr) & 1.000 & & & & & & & & & \\
\hline Economic freedom (ef) & -.001 & 1.000 & & & & & & & & \\
\hline The size of government (sog) & $.389^{* \star *}$ & $.436^{\star * *}$ & 1.000 & & & & & & & \\
\hline Protection of property rights (ppr) & .144 & $.391^{\star * *}$ & $.474^{\star \star \star}$ & 1.000 & & & & & & \\
\hline Government consumption (gcon) & $.589^{\star \star *}$ & $-.327^{\star *}$ & $.577^{\star \star \star}$ & .090 & 1.000 & & & & & \\
\hline Government transfers and subsidies (ts) & $.424^{\star * *}$ & $-.274^{\star *}$ & $.613^{\star \star *}$ & -.091 & $.884^{\star \star \star}$ & 1.000 & & & & \\
\hline Top marginal tax rate (tax) & -.032 & $.777^{\star * *}$ & $.536^{* * *}$ & $.581^{* \star *}$ & -.121 & -.123 & 1.000 & & & \\
\hline Industry growth rates (\%) (ind) & $.496^{\star * *}$ & -.013 & .012 & -.084 & $.287^{\star \star}$ & .108 & -.123 & 1.000 & & \\
\hline Service (\% of GDP) (ser) & $-.227^{\star}$ & $.782^{* * *}$ & -.086 & .029 & $-.699^{\star * *}$ & $-.653^{* * *}$ & $.553^{\star \star *}$ & -.037 & 1.000 & \\
\hline Employment (\%) (emp) & $.450^{* * *}$ & $-.390^{\star *}$ & $.450^{* * *}$ & .166 & $.821^{\star \star \star}$ & $.721^{\star \star \star}$ & -.032 & .144 & $-.702^{\star \star \star}$ & 1.000 \\
\hline Foreign direct investment inflows (fdin) & $-.193^{*}$ & $.422^{\star \star \star}$ & -.110 & $.231^{*}$ & $-.498^{\star \star *}$ & $-.453^{\star \star \star}$ & $.256^{\star *}$ & -.113 & $.475^{\star \star \star}$ & $-.401^{\star \star \star}$ \\
\hline
\end{tabular}

${ }^{* * *} \mathrm{p}<.01$

${ }^{* *} \mathrm{p}<.05$

${ }^{*} p<.1$

Source: Own calculations based on World Bank Data 
In regression analyses, protection of property rights, government consumption, and service industry had a significant and positive impact on economic growth while tax rates had a significant negative effect on GDP growth rates. The $R^{2}$ was 0.551 and F-statistic 9.802 at $p<.0001$ (Table 2).

Over the last 58 years, Greece had annual average GDP growth rates $2.62 \%$. In the first 20 years, when Greece was not a member of the European Union, the annual GDP growth rates were $6.2 \%$. In the first 20 years of its membership in the EU (before the Eurozone was established) the annual GDP growth rates were $1.58 \%$. From the first year of being in the Eurozone to the present, the annual GDP growth rates were $0.12 \%$. Overall, during its membership in the EU, Greece's economy grew at $0.85 \%$ rates annually.

Table 2: Coefficients: The effects of country variables on GDP growth rates (1970-2016)

\begin{tabular}{llllll}
\multicolumn{5}{c}{ Unstandardized Coefficients } & \multicolumn{2}{l}{$\begin{array}{l}\text { Standardized } \\
\text { Coefficients }\end{array}$} \\
Model & \multicolumn{1}{c}{ B } & Std. Error & Beta & $\mathrm{t}$ & Sig. \\
\hline (Constant) & -26.336 & 6.124 & & -4.300 & .000 \\
ppr & 1.209 & .590 & .306 & 2.050 & .047 \\
gcon & 3.527 & .795 & .862 & 4.435 & .000 \\
tax & -1.245 & .635 & -.408 & -1.961 & .057 \\
ind & .196 & .097 & .246 & 2.013 & .051 \\
ser & .073 & .029 & .601 & 2.491 & .017 \\
\hline Depend
\end{tabular}

Dependent variable: GDP growth rates

Source: Own calculations based on World Bank Data

The significant factors $\left(p<0.001\right.$ and $\left.R^{2}=0.988\right)$ in the GDP growth during Greece's independent years (1960-1980) were an excellent consumer price index, total reserves, including gold, and general government consumption (Table 3). Then, the Greece economy had an optimal structure.

Table 3: The effects of core economic factors on GDP growth rates (1960-1980)* before Greece's joining the EU

\begin{tabular}{|c|c|c|c|c|}
\hline & Coefficients & Standard Error & t Stat & $P$-value \\
\hline Intercept & $-2.5 E+09$ & $1.14 \mathrm{E}+09$ & -2.18637 & 0.043 \\
\hline Consumer price index & $4.47 E+09$ & $8.04 \mathrm{E}+08$ & 5.563976 & 0.001 \\
\hline Total reserves, including gold & -2.86069 & 0.9681 & -2.95495 & 0.001 \\
\hline Government consumption & 0.220578 & 0.014741 & 14.96363 & 0.001 \\
\hline
\end{tabular}

Dependent variable: Annual GDP growth rates

*After those years none of the involved factors were significant determinants of Greece' GDP grow

Source: Own calculations based on World Bank Data 
During Greece's membership in the EU, none of these factors were significant in determining GDP growth rates. GDP in most of the years did not grow but declined.

Hypotheses 1, indicating that economic growth rates will be much higher if a country has its own currency and economic sovereignty, is supported.

Hypothesis 2, indicating that economic growth rates will be much higher if a country has its own currency and economic sovereignty, is also supported.

\section{Conclusion}

Membership in such bureaucratized unions as the EU is not always yields a positive outcome for peripheral countries as Greece, Spain, Ireland, and some other countries of the EU. Losing economic sovereignty is a significant disaster for a country which cannot make independent economic decisions on domestic and foreign economic policies. Therefore, a country stops being a country. It becomes a province of a larger territorial system. Larger and stronger countries become the center of the system and benefit the most from the union as it took place in the Soviet Union.

\section{Reference}

DIMITROVA, A. (2010) The European Union and the European states. The Public Administration Review. Vol. 70 , No. 1, s. 326-327.

DUDIN, M.N.; GAYDUK, V.I.; SEKERING, V.D.; BANK, S.V. and GOROBOVA, A.E. (2016) Financial crisis in Greece: Challenges and threats for the global economy. International Journal of Economics and Financial Issues. Vol. 6, No. 5, s. 1-6.

KUFORIJI, J.O. (2016) Greece financial crisis: The genesis, implications, and policy options. Journal of Applied Financial Research. Vol. 1, s. 55-74.

PEGKAS, P. (2018) The effect of government debt and other determinants on economic growth The Greek experience. Economies. Vol. 6, No. 10, s 1-19.

RINEGAR, J. (2012) The creation (and destruction) of the Greek economic miracle. Indian Journal of Economics and Business. Vol. 11, No. 1, s. 121-137.

SHMIDT, V.A. (2006) Democracy in Europe: The EU and national polities. Oxford University Press, Oxford, UK. 